\title{
Risks of Psychomanteum Experimentation
}

To the Editor:

I heartily agree with Bruce Greyson's caution about Raymond Moody's psychomanteum, expressed in his review in the Summer 1996 issue of the "Journal" of Moody and Paul Perry's Reunions (Greyson, 1996). Although all of Moody's accounts of meetings with the deceased cited in Reunions (Moody and Perry, 1993) were pleasant and healing, 
I find the mirror's capacity for calling upon and being visited unawares by spirits to be personally chilling. Like the "bad trips" of the 1960s psychedelic pioneers or the "flashbacks" many experienced afterwards, such encounters could possibly tear apart the unsuspecting explorer.

In one case I know, an ardent follower of Moody's book made her own device. She invited several of her metaphysically curious friends, including myself, to visit and perform our own experiments. Two of us declined, while she and two others ventured into this basement "Theater of the Mind." The woman and her two friends have since suffered severe emotional and family trauma, while those of us who shied away have not.

One of these people, although always eccentric and hypersensitive, went rapidly downhill in the months following her completion of the psychomanteum. She became emotionally unbalanced, nearly died from several ailments that flared up all at once, separated from her husband, and disconnected her phone. A second turned against her friends; her hate mail and phone calls led me to fear for my safety, as she lived nearby and we had car-pooled to several events together. She alternated between rage and depression, but saw no need for any medical help. Even sadder was the fate of the third participant, a near-death experiencer who seemed to be very stable and well adjusted prior to this time, despite the rape and murder of her teenage daughter several years ago. Her marriage (to a man who had an NDE in the recent past) broke up, and her daughter, the twin of the murdered daughter who was visited in the psychomanteum, ran off with a man who had previously been jailed for kidnaping her.

Are these cases merely coincidence, or cause and effect? I don't think this can be proven, but I personally am glad I resisted the temptation to dabble in such "black arts."

\section{References}

Greyson, B. (1996). [Review of Reunions: Visionary encounters with departed loved ones]. Journal of Near-Death Studies, 14, 281-285.

Moody, R. A., and Perry, P. (1993). Reunions: Visionary encounters with departed loved ones. New York, NY: Villard.

Beverly Brodsky

12031 Via Felicia

El Cajon, CA 92019 